\title{
Illuminating the gap: An overview of classroom-based arts education research in Australia
}

Dr Christopher Klopper

Griffith University

Bianca Power

Charles Sturt University

\begin{abstract}
Arts education is an internationally recognized term referencing education through the arts. The term arts is seen to encompass different things in different contexts, including but not limited to the performing arts- music, dance, drama, and theatre; visual arts, media, industrial arts, and literary arts. In this article, the authors provide an overview to date of classroom-based arts education research in Australia. In so doing, the 'gap' in the literature describing and discussing classroom-based arts education is illuminated. We call for attendance to classroom-based arts education research in Australia given that the heart of curriculum transfer and transformation is in the classroom. We offer a research methodology and design of practitioner enquiry to empower and enlighten collective knowledge sharing of professional practice. Such attendance will establish a base that can bring about sustained policy and practice change.
\end{abstract}

Keywords: arts education, classroom-based research, practitioner enquiry, collective knowledge sharing of professional practice

Word count: 5354 


\section{Introduction}

Arts education provides students with valuable opportunities to experience and build knowledge and skills in self expression, imagination, creative and collaborative problem solving, communication, creation of shared meanings, and respect for self and others. Engagement in quality arts education has also been said to positively affect overall academic achievement, engagement in learning, and development of empathy towards others (Australian Council for Educational Research 2004; Board of Studies NSW 2006; Cornett 2007; Russell-Bowie 2006). The integration of the arts in education is an internationally recognized phenomenon: it is a modern trend to organize the curriculum in an integrated and interdisciplinary manner (Aaron 1994; Barrett 2001; Burton 2001; Chrysostomou 2004; Hauptfleisch 1997; Klopper 2004; Russell-Bowie 2006, 2009a; Snyder 2001). The 'arts' is seen to encompass different things in different contexts, including but not limited to the performing arts (music, dance, drama, and theatre), visual arts, media, industrial arts, and literary arts. Currently in Australia, each educational jurisdiction ${ }^{1}$ has developed its own frameworks and repertoire of describing what happens in arts education learning. In this article arts education is used as an encompassing umbrella term referenced to The Arts learning area in the Australian curriculum.

Despite the intrinsic value of arts education a number of studies throughout Australia and internationally have indicated the inadequacy of arts education in primary schools. The vast majority of these studies have focused on music and visual arts, with few on dance or drama. Fewer still have explored the collective approach to arts education. Wiggins \& Wiggins (2008) note that there have been exceedingly few studies reporting on what is actually happening at a classroom level in music education; or in other words, what are teachers in our classrooms actually doing in relation to teaching music? What is the nature of classroom practice of music education? This article expounds the similar disparity that exists in relation to classroom-based research of visual art, dance, drama, and arts education. It intends to inform policy, provide evidence and illuminate the gap in the existing literature.

\section{National reviews of arts education in Australia}

The most recent national arts education reviews in Australia are the National Review of School Music Education (Pascoe et al. 2005) and First We See: The National Review of Visual Education (Davis 2008). The National Review of School Music Education (Pascoe et al. 2005) was commissioned by the Australian Government in 1994. In March 1995 the team of researchers aimed to investigate and identify: (a) the current quality of teaching and learning of music in Australian schools; (b) factors that affect the quality and status of teaching of music in Australian schools; (c) examples of best practice of teaching and learning of music both in Australian schools and schools overseas; and (d) key recommendations, principles and priorities for enhancing school music education.

Sixteen specific recommendations for improving the practice and status of music education in Australian primary, secondary, and central schools were made. These included: enhancing the status of school music education; improving equity of access to and opportunities to engage in sequential and developmental music education; improving pre-service music education for generalist teachers;

\footnotetext{
${ }^{1}$ Education in Australia is primarily the responsibility of states and territories. There are six states and two mainland territories constituting the Commonwealth of Australia. Each state or territory government provides the funding and regulates the public and private schools with its governing area, the federal government funds the universities, but these set their own curriculum.
} 
improving pre-service music education for specialist classroom teachers; improving in-service professional development of music education; greater support for the implementation of music education including student access to learning a musical instrument, vocal music, and music technology; promotion of partnerships between schools and key music and arts organizations; provision of specialist music teachers in primary schools; and accountability of teachers for demonstration of quality music programs.

First We See: The National Review of Visual Education (Davis 2008) was commissioned and released jointly by the Australian Council for the Arts and the Department of Education, Employment and Workplace Relations in cooperation with the Department of Environment, Water, Heritage and the Arts. Submissions were called for from key stakeholders, the curriculum documents of each state and territory mapped, surveys distributed to Australian universities providing teacher education programs and to schools across Australia, and a number of case studies conducted in a variety of settings. Four key recommendations emerged: separation of the visual education curriculum from the performing arts; improvement of pre-service and in-service training in visual education for both primary generalist and secondary specialist teachers; establishment of partnerships between schools and external organizations to contribute to visual education; and development of a national visual education research agenda.

\section{Arts education in pre-service teacher education}

Both national reviews identified a need for improvement of pre-service teacher education in the art forms. Issues of teacher preparedness influence the quality of primary students' artistic learning and development in Australia, with a significant 'gap' witnessed between the expectations of curriculum frameworks and initial teacher education in arts education (Alter et al. 2009). The key interrelated issues associated to pre-service teachers and arts education include pre-service teachers' confidence, attitudes, self-efficacy, and prior experiences in the art forms. The value pre-service teachers ascribe to arts education and their self-efficacy and confidence in teaching the art forms affect both the amount and quality of arts that they teach once in schools (Hudson and Hudson 2007; Jeanneret et al. 2006).

A number of studies have indicated what pre-service teachers bring with them in the way of background experiences in music, visual arts, drama, and dance affect how these individuals participate in workshops on each art form at university as well as how and to what extent they teach arts education when they are in-service (Dunkin 2004; Jeanneret et al. 2006; Klopper 2007; Russell-Bowie and Dowson 2005; Wright 1999). These studies highlight the emotional 'baggage' that individuals bring with them when entering pre-service teacher education and undertaking courses in the field of arts education.

Wiggins \& Wiggins (2008) make the point that when prospective teachers enter pre-service education in the United States they have had approximately twelve years of comprehensive and sequential instruction in mathematics, English, and science, while their last formal music instruction in schools may have occurred at the age of twelve or earlier. Much the same can be said of prospective teachers entering pre-service in Australia, with science and mathematics being compulsory subjects taught each semester of each year from K-10, and English compulsory from K-12, music, visual arts, dance, and drama are only mandated from K-8 (Australian Government 1990). This translates into prospective student's experiences in arts education being distant and in many cases sporadic. Wiggins \& Wiggins suggest, "We would not allow someone who had stopped studying mathematics at the fifth grade level to teach mathematics. We would be appalled at the idea that someone could teach language arts if he or she had not read a book or written a word since the age of eleven" $(2008$, p.4). Teacher education 
institutions need to account for this lack of content knowledge and endow these prospective teachers with skills and knowledge empowering the capacity to teach arts education effectively in schools.

In Australia the National Review of School Music Education (Pascoe et al. 2005) indicated that preservice teacher education does not adequately prepare generalist primary teachers to teach music in schools, attributing this in part to the reduction in hours dedicated to music in pre-service teacher education. Montague (2004) also draws attention to this reduction in hours in New South Wales (NSW) universities and the subsequent negative effect on teacher confidence in music education. The review identified improvement of pre-service teacher education as an immediate priority in the improvement of music education in Australian schools.

Similarly, First We See: The National Review of Visual Education (Davis 2008) identifies inadequate preservice teacher training in visual education as a contributing factor to the poor state of visual education in Australian schools. Duncum (1999) goes as far as describing pre-service teaching of primary generalists as the "black hole" of art education (p. 15). The national review recommends that appropriate pre-service training to prepare generalist primary teachers for teaching visual education be instituted.

In the area of visual art education in pre-service teacher education, Hudson \& Hudson (2007) studied the perceptions of preparedness for teaching visual art education of 87 final-year pre-service generalist primary teachers in a NSW university. The authors surveyed these students using a survey instrument consisting of 39 close-ended items in Likert scale format, derived directly from the requirements of the visual art section of the NSW Creative Arts K-6 Syllabus (Board of Studies NSW 2006). While participants in this study indicated that they believed they were generally prepared to teach visual art to primary school students, more than 10 per cent indicated that they did not feel they could provide a large portion of the syllabus requirements ( 20 of the 39 items).

In the field of drama education in pre-service teacher education, Wright (1999) conducted an exploratory study involving three years of successive pre-service generalist teacher education students in a NSW university. The study investigated the manifestations of 'drama anxiety' experienced by these students and what the students felt could help with this. Two distinct manifestations of drama anxiety were found to be apparent: physical expression, where an individual's anxiety has a physical effect on them such as shaking, feeling weak in the knees, feeling sick, or stuttering; and a state of feeling, where there are no physical symptoms of the anxiety, just an anxious or nervous feeling. The most effective ways to minimize and/or overcome 'drama anxiety' were established: development of basic skills in drama; clear articulation of teacher expectations; and group work (not singling out the individual).

Wright (1999) stated that these findings have pedagogical implications for teaching of students at any level, although the findings of this research have limited generalizability due to three features of the research - conducted by one lecturer/tutor, in one specific university, and only involving second year pre-service teachers. Additional research is needed with primary school students, pre-service teachers in an earlier or later year of their course, and/or at different institutions with a different lecturer/tutor before broad claims to generalizabilty can legitimately be substantiated.

On the subject of dance education in pre-service teacher education, Dunkin (2004) studied the prior teaching and dance experiences and preparedness to teach dance of 99 pre-service generalist teacher education students ( 90 female, 9 male) in a Californian university completing a one-semester course entitled "Creative Dance for Children". Using a qualitative methodology, students reflected on various questions at different points during the semester. Approximately $50 \%$ of students indicated that they 
had no prior outside of school dance experience, and $32 \%$ could not recall participating in dance activities at school. Of those who recalled dance activities at school, $36 \%$ had pleasant memories of this while $64 \%$ remembered unpleasant experiences. When asked how their own experiences of dance in school might influence their decision to present dance in the classroom, all those who had positive experiences indicated that they were excited and positive about doing so, as did five others who had reported negative personal experiences. Other respondents indicated that they would teach dance but with particular restrictions. Restrictions linked to their own bad experiences. At the completion of this one semester course, $94 \%$ of students indicated that they felt motivated to teach dance in schools, and $95 \%$ indicated that they felt prepared to teach dance in schools. Despite this, $89 \%$ of these students also indicated that they anticipated obstacles to their teaching of dance in schools, including negative (elementary school) student attitudes and their own (teachers') shortcomings.

Arts education, as an umbrella term, in pre-service teacher education has seen a limited number of studies. Russell-Bowie \& Dowson (2005) report on the results of a small study within a larger study on students' attitudes: Creative Arts National and Overseas Associates (CASANOVA). The study involved pre-service generalist primary school teachers from five countries (Australia, Namibia, South Africa, United States of America (Illinois) and Ireland), examining six specific hypotheses relating to students' background and confidence in the artforms. These hypotheses were: for all students higher levels of background in the arts will lead to more confidence in teaching the arts; girls will have more confidence in teaching the arts regardless of background; the interaction of sex and background will influence confidence in teaching the arts; males and females will exhibit different patterns of background and confidence across the arts; there will be a moderate relationship between background in one arts area and background in other arts areas; and there will be a moderate relationship between confidence in one arts area and confidence in other arts areas.

In every art form background was found to be a strong and positive predictor of confidence and enjoyment in teaching. In the areas of music, dance, and visual art females were found to be much more likely to report confidence and enjoyment in teaching these art forms than their male counterparts. In music background was found to be a stronger predictor of confidence for females than for males. A moderate relationship was found between background in one arts area and background in other arts areas, and a weak to moderate relationship between confidence in one arts area and confidence in other arts areas. One limitation of the study is that some of the students surveyed were in their first year of pre-service teacher education, and others in their second, third, or fourth year. It is plausible that this could influence the students' confidence for teaching in general, however the author does not mention accounting for this at all. Further to this, due to the survey being completed by students from five different countries - some in which English is not a first language - all items on the survey may not have been interpreted in the same way by each respondent.

The key issue revealed is the inadequacy of arts education in pre-service teacher education preparation for the expectations of the arts curriculum (Alter et al. 2009; Davis 2008; Duncum 1999; Pascoe et al. 2005). The reduction in hours dedicated to arts in pre-service teacher education (Montague 2004; Pascoe et al. 2005) and pre-service teachers' initial lack of content knowledge and/or background experiences in the arts upon entering university (Dunkin 2004; Hudson and Hudson 2007; Jeanneret et al. 2006; Russell-Bowie and Dowson 2005; Wiggins and Wiggins 2008; Wright 1999) present difficulty for teacher educators who must attempt to account for this lack of knowledge and experience in a short amount of time. Lack of background in arts education combined with insufficient time dedicated to this subject during pre-service teacher education inevitably results, for many, in a lack of confidence in teaching the subject once in schools. 


\section{Arts education in primary schools}

The literature on this topic focuses predominantly on the music component, though there are suggestions that similar issues exist within visual arts, dance, and drama education. Russell-Bowie (1993, 2002), Jeanneret (2006), and Stevens (2001) describe how little has occurred in the way of improving music education in schools in the past few decades, despite several national enquiries into this issue. Stevens advocates the importance of history informing future decisions, suggesting that current issues in music education are a result of either change or failure to change in response to previously identified problems.

In NSW, while it is a mandatory requirement in government schools that students are taught music in each year of schooling from Kindergarten to Year 6, studies have shown that this does not always occur (Montague 2004; Pascoe et al. 2005). As a result, music education and development of students' skills in K-6 music is not always continuous or sequential. Montague (2004) attributes this lack of continuous and sequential music education in part to inadequacies in teacher knowledge and skill development in both pre-service and in-service training. Montague makes further claim that the quality of music education taught by generalist teachers cannot be expected to match the expectations of the syllabus without greater support in the way of regular in-service professional development subsequent to increased hours of pre-service training in music education.

In many countries the responsibility for teaching music lies with generalist teachers in primary schools (Wiggins and Wiggins 2008), as is the case in Australia, where the generalist teacher is predominately responsible for teaching arts education in the majority of classrooms (Alter et al. 2009; Davis 2008). Alexander et al. (cited in Alter et al. 2009) projected that teaching the primary education curriculum is "a far too demanding expectation of a generalist teacher's subject-knowledge" (p. 18) and that often arts education is the subject that suffers most of all. Generalist teachers have been perceived both by themselves and others as lacking the experience, training, and subject knowledge to teach arts education effectively (Alter et al. 2009). Wiggins \& Wiggins (2008) reported that the quality of music instruction provided by generalist teachers is dependant upon both their knowledge of pedagogy and their knowledge of and background in music. They also found that the majority of teachers were, in their opinion, unable to 'teach music with integrity' due to their lack of understanding of music pedagogy, and that this in turn caused these teachers to lack confidence in teaching music.

Alter (2007) investigated the use of visual art education to promote and foster creative and higher order thinking in the primary school classrooms of generalist teachers. While the teachers in this study believed that they created a quality-learning environment in which creative and higher order thinking was occurring, they were unable to articulate how they were doing so, or how they knew that this was occurring. The observational data in the study suggested that higher order thinking did occur in art appreciation activities, but that there was little scope for creativity in either classroom.

Anderson (2003) conducted a study involving two NSW primary school teachers with an interest in drama, to investigate the realities of teaching drama experienced by these individuals. The key theme emerging from this research was lack of support for the teaching of drama, from the education system itself as well as in some cases from other teachers. Anderson (2003) also points out the particular difficulty teachers face in teaching non-core curriculum subjects (such as drama) during the beginning 'survival' years of teaching.

Chappell (2007) investigated the perceptions of and approaches to creativity of three specialist dance teachers in upper primary dance education in the United Kingdom. The teachers involved in this study 
emphasized the importance of particular teacher attitudes to 'fuelling' the creative process: passionate engagement in dance; and confidence in participating in and teaching it. The importance of engaging in creativity at three levels (individual, collaborative, and communal) was accentuated.

Pedagogical issues expressed by the participating teachers included students' lack of prior knowledge and experience in dance, students' overdependence on language-based ways of knowing (wanting to 'talk it out') as opposed to embodied ways of knowing (physically experimenting with movements), and successful incorporation of individual and collaborative creative practices. These teachers also reported a lack of support from other teachers and pressure from performance expectations.

Alter et al.'s (2009) study of 19 Australian generalist primary school teachers' perspectives of arts education signified a need for greater support of qualified teachers in the classroom, with the majority of participants in the study indicating that they had little or no in-service training or support immediately prior to or following the introduction of the then most recent NSW Creative Arts K-6 syllabus. Specific to the music component of Creative Arts, Jeanneret (2006), Russell-Bowie (2009b), and Pascoe et al. (2005) acknowledge the lack of support given to primary generalists in relation to teaching music and advocate a need to provide greater support for practicing teachers through in-service training opportunities. While in the 1980s there was a Department of Education and Training music consultant in each region of NSW and a network of district advisory teachers, NSW is now one of the few Australian states that currently has one music consultant in the state specifically employed to provide teachers in government schools with support (Jeanneret 2006).

There has been substantial debate over the perceived benefits of arts education being taught by a generalist teacher as opposed to a teacher specializing in that field (Russell-Bowie 2006). Arguments for generalist as opposed to specialist teachers are primarily based around issues of pastoral care, and the belief that classroom teachers have a better knowledge of and relationships with students as well as being in a better position to integrate the arts into the everyday curriculum (Russell-Bowie 2006). A lack of confidence by generalist teachers has been identified as an obstacle to effective teaching and learning in arts education (Alter et al. 2009). In Australia problems in relation to primary teacher self-efficacy in teaching of the arts along with values for Creative Arts were identified in both the National Review of Music Education (Pascoe et al. 2005) and the National Review of Visual Education (Davis 2008). In relation to music education Montague (2004, p. 143) suggests that "many teachers lack the confidence to provide ongoing music education for their students". Duncum $(1999$, p. 15) also asserts that in relation to visual art many generalists believe "if they can't draw, they can't teach art" and subsequently explore numerous materials as opposed to actually teaching art skills.

Another of the key difficulties to implementing arts education is that of the 'crowded curriculum'. A lower educational priority is attributed to arts education in the curriculum, both by schools and policy makers (Dimitriades et al. 2009; Smith and Southcott 2004), as the arts are marginalized because of the push for a back to basics approach focusing on literacy and numeracy. Anderson (2003) suggests that due to the crowded curriculum even if a curriculum area is mandated it must also be attractive to teachers and well supported to ensure that it is actually taught.

In 2004 the Australian Council for Educational Research (ACER) examined four best practice arts education programs operating in Australian schools: Learning to learn through the Arts@Direk Primary School, South Australia; SCRAYP - Youth Arts With an Edge: Footscray Community Arts Centre, Victoria; The Northern Territory Indigenous Music Education Programme; and The Northern Territory Boys' Business Music Programme (Australian Council for Educational Research 2004). The study aimed to investigate the impact of each arts program on students' academic progress, engagement with learning, 
and attendance at school, as well as identifying attributes of arts programs deemed to be of particular benefit to students. Overall there were no statistically significant results to indicate that involvement in these programs increased academic or learning outcomes, however there was evidence across the four sites studied that these arts programs did encourage students to engage with school and with learning. It was also found that school attendance increased for indigenous students involved in the Northern Territory programs. Attributes of these arts programs indentified as particularly beneficial to students were: a charismatic/inspirational role model for students; positive reinforcement of students' achievements; authentic activities working towards public presentation; familiar/negotiated procedures; and a 'safe' environment for risk taking. As with the vast majority of studies concerning arts education, the nature of classroom practice was not reported on, only the perceived effects of it.

\section{Arts education classroom-based practice}

The literature describing classroom practice of arts education in primary schools is severely limited. Over a decade and a half ago, Russell-Bowie (1993) conducted a quantitative study surveying the music education practices of 400 primary school teachers from four departmental regions of NSW. This study reported on practices in relation to the 1984 NSW Music Syllabus (Department of Education NSW 1984).

Russell-Bowie (1993) investigated the state of music education K-6 classroom practice in NSW primary schools. The research indicated that music education in the classrooms of the respondent teachers was generally ineffective, with little excellence or equity in the practice or priority of music in their schools or individual classrooms. The two main barriers to effective music teaching expressed by the teachers were lack of time and lack of personal music experience. Lack of departmental support and in-service training were also identified as contributing to this.

Peers (2008) investigated the attitudes of Victorian primary school generalist teachers to visual arts education, and these teachers' practice of visual arts education. Though the findings cannot be taken as a representative sample, the responses of the five participants indicated that they supported the idea of specialist teachers being appointed to every school, that they personally dedicate more than one hour a week to visual arts, and that they each value visual arts in the curriculum. Peers continues by suggesting a number of factors that may have contributed to the poor response rate for the questionnaire: the fact that the study required teachers to respond online; the employment of specialist teachers heightening disinterest for visual art among generalist teachers; and the fact that the researcher asked school principals to respond in writing to an initial request for participation in the research.

Saebo (2009) studied the classroom practice of Norwegian drama. Group interviews, individual interviews, and an online questionnaire were utilized in this research to ascertain the effectiveness of classroom practice of drama in these schools. The author found that predominantly superficial learning experiences occurred in instances where the teacher lacked the knowledge and understanding necessary to structure teaching and learning in such a way as to foster particular creative processes. On other occasions when the teacher effectively used process drama, students were fully engaged in the learning process. Overall it was found those teachers' creative competencies and their reason for doing drama (i.e. because it is required or because they value and enjoy it) were two key factors influencing the effectiveness of the drama teaching and learning practices that occurred. The nature of classroom practice was not discussed in depth, only the effectiveness of it.

Debenham \& Lee (2005) report on the observations they made on their own and each others' classroom practice of dance during a three day interval of teaching nine to eleven year old students in the United States. They found that they had a number of teaching practices in common: they were student- 
focused; grounded in metaphor and imagery; created a positive atmosphere; and often needed to 'go back' during a lesson to redress necessary concepts and skills.

All of these studies report that personal experience in arts education, and teachers' creative abilities influence the effectiveness of their music (Russell-Bowie 1993) and drama (Saebo 2009) teaching, as do teachers' attitudes towards the art form (Saebo 2009). Music education in the schools studied was described as sub-standard (Russell-Bowie 1993; Wiggins and Wiggins 2008) and a lack of departmental support and in-service training was also found (Russell-Bowie 1993). Wiggins \& Wiggins (2008, p. 3-4) assert that:

we need to present policy makers with descriptions of what actually occurs in primary classrooms when generalist teachers teach music so they will have accurate criteria for making decisions about the future of music education in the schools.

Lamenting the lack of Australian research in arts education, Bamford (cited in Gibson and Anderson, 2008, p.103) argues:

While substantial studies into the benefits of arts education have been undertaken in the USA and the UK, very little research has been conducted into the impact of arts education in Australian schools... There is urgent need for a detailed study of the impact of arts programmes within the context of Australian schools.

We reiterate this sentiment and call for attendance to the impact of these arts education programmes but further the call to include a closer examination of classroom-based arts education practice in Australia. The heart of curriculum transfer and transformation is in the classroom. What are teachers in our classrooms actually doing in relation to teaching arts education? What is the nature of classroom practice of arts education?

Schwab was an important spokesperson for the importance of the structure-of the-discipline in the school curriculum, largely due to his involvement in the curriculum reform movement and, particularly, a series of structure-of-the-disciplines essays he wrote in the 1960's (Schwab, 1964b, Schwab, 1962, Schwab, 1964a). His concept of translation was articulated in the paper "The Practical: Translation Into Curriculum" (Schwab 1973), which emphasised the understanding of the learner, instead of the subject matter of an academic discipline, as the crucial point for transformation or translation. Further to this, Potgieter and Klopper support (2006): "[a]s educators we have to learn from our learner's. We have opportunity to allow what we learn to influence our teaching". Schwab viewed transformation as the fundamental task of curriculum development that cannot be fully accomplished by an individual classroom teacher. It requires the collaboration of various talents including classroom teachers, subject matter experts, and curriculum specialists who are engaged in a process of collective knowledge sharing of professional practice, with practical and eclectic treatment of a variety of curriculum factors. We propose using a research design of collaborative inquiry to be appropriate. The major idea of collaborative inquiry is to "research 'with' rather than 'on' people" (Bray et al. 2000). It emphasizes that all active participants are fully involved in research decisions as co-researchers. Collaborative inquiry creates a research cycle among four different types of knowledge: propositional knowing (as in contemporary science), practical knowing (the knowledge that comes with actually doing what you propose), experiential knowing (the feedback we get in real time about our interaction with the larger world) and presentational knowing (the artistic rehearsal process through which we craft new practices). We offer the design of practitioner enquiry to empower and enlighten collective knowledge 
sharing of professional arts education practice. Such attendance will establish a base that can bring about sustained policy and practice changes.

Table 1 provides a tabulated overview of research in the field of arts education and illustrates the plethora of research in the fields of music education (33 studies: 41\%) and visual arts education (30 studies: $37 \%$ ), with comparatively little on drama education (8 studies: $10 \%$ ), dance education (5 studies: $6 \%$ ), and arts education as an umbrella term (5 studies: $6 \%$ ). The large majority of research in all of these areas is on arts education in higher education (38 studies: $47 \%$ ), with slightly less on arts education in primary schools (27 studies: $33 \%$ ) and significantly less on arts education classroom practice (16 studies: $20 \%)$. There does not appear to be research documenting classroom-based practice of arts education.

\section{Table 1: Overview of aims of research detailing arts education in pre-service teacher education, primary schools, and primary classroom-based practice. ${ }^{2}$}

<insert Table 1>

\section{Implications for further research}

Arts education in primary schools has been described as falling short of expectations in Australia as well as internationally. In many instances, pre-service and in-service teacher education does not provide adequate preparation or support for generalist teachers to meet the expectations of arts education curriculum. The key overarching issues identified in the extant literature include: teachers' personal experience in arts education; adequacy of pre-service teacher education; teacher confidence; the state of arts education; the perceived 'crowded curriculum'; lack of support given for in-service teachers; and the generalist versus specialist debate. Lack of confidence felt by generalists in relation to arts education has been identified as influencing how these individuals initially engage in pre-service teacher education, and the amount and quality of arts education they teach once in schools. Values and attitudes towards arts education felt by teachers and the education system as a whole has also been seen as a factor in this, as has the perceived crowded curriculum.

While this is all quite relevant and essential to understanding the current state of arts education, what is missing are close encounters with curriculum transfer at a classroom level - what is the nature of arts education classroom practice? The reviewed studies do not provide this detail. Gibson \& Anderson (2008) emphasize the need for innovative research to explore the links between education and the arts in the Australian context so as not to be left behind by the recent surge underway in the United States of America and the United Kingdom. It is crucial that an investigation of current practice be produced for principals, teachers, pre-service teacher educators, curriculum developers, and interested stakeholders to understand from the ground up the mechanisms of arts education, and work towards enhancing the practice of arts education in Australian school classrooms.

${ }^{2}$ Australian studies are in bold while studies conducted in other countries are in italics. The numbering of studies is not in any way designed to be indicative of value, importance, or relevance, but rather adds to the ease at which the reader can see the number of studies in each area. 
Table 1

\begin{tabular}{|c|c|c|c|}
\hline & $\begin{array}{c}\text { Arts education in } \\
\text { Pre-service Teacher Education }\end{array}$ & $\begin{array}{l}\text { Arts education in } \\
\text { Primary Schools }\end{array}$ & $\begin{array}{c}\text { Arts education } \\
\text { K-6 Classroom Practice }\end{array}$ \\
\hline Music & $\begin{array}{l}\text { 1. Auh, } 2007 \\
\text { 2. Baker, } 2007 \\
\text { 3. Ballantyne, } 2006 \\
\text { 4. Bernard, } 2009 \\
\text { 5. Bolton, } 2000 \\
\text { 6. D'Ombrain, } 1974 \\
\text { 7. Jeanneret, } 1994 \\
\text { 8. Klopper, } 2007 \\
\text { 9. Pascoe et al., } 2005 \\
\text { 10. Russell-Bowie, } 2009 a \\
\text { 11. Russell-Bowie, } 2009 b \\
\text { 12. Russell-Bowie, } 2002 \\
\text { 13. Temmerman, } 1997 \\
\text { 14. Gerges, } 2001 \\
\text { 15. Gifford, } 1993 \\
\text { 16. Hewitt, } 2002 \\
\text { 17. Jones, } 2007 \\
\text { 18. Marsh, } 2000\end{array}$ & $\begin{array}{l}\text { 1. Jeanneret, } 2006 \\
\text { 2. Montague, } 2004 \\
\text { 3. Pascoe et al., } 2005 \\
\text { 4. Pitts \& Davidson, } 2000 \\
\text { 5. Smith \& Southcott, } 2004 \\
\text { 6. Stevens, } 2001 \\
\text { 7. Temmerman, } 2008 \\
\text { 8. Bresler, } 1996 \\
\text { 9. Gamble, } 1988 \\
\text { 10. Mills, } 1989 \\
\text { 11. Wiggins \& Wiggins, } 2008\end{array}$ & $\begin{array}{l}\text { 1. Pascoe et al., } 2005 \\
\text { 2. Russell-Bowie, } 1993 \\
\text { 3. Wiggins \& Wiggins, } 2008 \\
\text { 4. Wong, } 2005\end{array}$ \\
\hline Visual Art & $\begin{array}{l}\text { 1. Ashton, } 1999 \\
\text { 2. Davis, } 2008 \\
\text { 3. Grauer, } 1999 \\
\text { 4. Hudson \& Hudson, } 2007 \\
\text { 5. Victorian Government Education } \\
\quad \text { and Training Committee, } 2005 \\
\text { 6. Bamford, } 1996 \\
\text { 7. Brouilette \& Burns, } 2005 \\
\text { 8. Green \& Mitchell, } 1998 \\
\text { 9. Henry \& Lazzari, } 2007 \\
\text { 10. Millbrandt, } 2006 \\
\text { 11. Nakamura, } 1999 \\
\text { 12. S. Wright, } 2005 \\
\text { 13. Zimmerman, } 1994\end{array}$ & $\begin{array}{l}\text { 1. Alter, } 2007 \\
\text { 2. Davis, } 2008 \\
\text { 3. Chapman \& Golding, } 2005 \\
\text { 4. Davidson \& Michener, } 2001 \\
\text { 5. Hall, Thomson, \& Hood, } 2007 \\
\text { 6. Hargreaves, Lamont, Marshall, \& } \\
\quad \text { Tarrant, } 2002 \\
\text { 7. Harland et al., } 2005 \\
\text { 8. Upitis, } 2005 \\
\text { 9. Waldorf, } 2002\end{array}$ & $\begin{array}{l}\text { 1. Davis, } 2008 \\
\text { 2. Peers, } 2008 \\
\text { 3. Bachar \& Glaubman, } 2006 \\
\text { 4. David, } 2001 \\
\text { 5. Hargreaves, Lamont, Marshall, \& } \\
\quad \text { Tarrant, } 2002 \\
\text { 6. Qualifications and Curriculum } \\
\quad \text { Authority, } 2002 \\
\text { 7. Seidel, Winner, Hetland, \& Tishman, } \\
\text { 2007 } \\
\text { 8. Woodworth et al., } 2007\end{array}$ \\
\hline Drama & $\begin{array}{l}\text { 1. Prior, } 2005 \\
\text { 2. Simons, } 2003 \\
\text { 3. Wright, } 1999 \\
\end{array}$ & $\begin{array}{l}\text { 1. Anderson, } 2003 \\
\text { 2. Prior, } 2005 \\
\text { 3. Wright \& Gerber, } 2004\end{array}$ & $\begin{array}{l}\text { 1. Saebo, } 2009 \\
\text { 2. Wales, } 2009\end{array}$ \\
\hline Dance & $\begin{array}{l}\text { 1. Dunkin, } 2004 \\
\text { 2. Rolfe, } 2001\end{array}$ & 1. Chappell, 2007 & $\begin{array}{l}\text { 1. Debenham \& Lee, } 2005 \\
\text { 2. Donald, } 1992\end{array}$ \\
\hline $\begin{array}{l}\text { Arts education } \\
\text { as an umbrella } \\
\text { term }\end{array}$ & $\begin{array}{l}\text { 1. Jeanneret et al., } 2006 \\
\text { 2. Russell-Bowie \& Dowson, } 2005\end{array}$ & $\begin{array}{l}\text { 1. Alter, Hays, \& O’Hara, } 2009 \\
\text { 2. Barrett \& Smigiel, } 2003 \\
\text { 3. Fraser, } 2007\end{array}$ & \\
\hline
\end{tabular}




\section{References}

Aaron, J. (1994), 'Integrating music with core subjects', Music Educators Journal, 80: 6, pp. 27-33.

Alter, F. (2007), 'Understanding the role of critical and creative thinking in Australian primary school visual arts education', In 2nd International Arts in Early Childhood Conference.

Alter, F., Hays, T. and O'Hara, R. (2009), 'Creative arts teaching and practice: Critical reflections of primary school teachers in Australia', International Journal of Education \& the Arts, 10: 9, pp. 1-21.

Anderson, M. (2003), 'I took the road less travelled and that has made all the difference': The professional journeys of two primary drama educators', Drama Australia Journal, 27: 1, pp. 5-14.

Australian Council for Educational Research. (2004), Evaluation of school-based arts education programmes in Australian schools, Canberra.

Australian Government. (1990), Education Act 1990, Canberra: Author.

Barrett, J.R. (2001), 'Interdisciplinary work and musical integrity', Music Educators Journal, 87: 5, pp. 2731.

Board of Studies NSW. (2006) Creative arts K-6 syllabus, Sydney: Board of Studies NSW.

Bray, J. N., Lee, J., Smith, L. L. \& Yorks, L. (2000) Collaborative inquiry in practice, Thousand Oaks, Sage.

Burton, L. H. (2001), 'Interdisciplinary curriculum: Retrospect and prospect', Music Educators Journal, 87: 5, pp. 17-21.

Chappell, K. (2007), 'Creativity in primary level dance education: Moving beyond assumption', Research in Dance Education, 8: 1, pp. 27-52.

Chrysostomou, S. (2004), 'Interdisciplinary approaches in the new curriculum in Greece: A focus on music education', Journal for Research in Music Education, 105: 5, pp. 23-29.

Cornett, C. (2007), Creating meaning through literature and the arts, New Jersey: Pearson Education.

Davis, D. (2008), 'First we see: The national review of visual education', (ed.), Science and Training Department of Education: Australian Government.

Debenham, P. and Lee, M. A. (2005), 'Teaching backwards: Reflections on an unacknowledged teaching practice', Journal of Dance Education, 5: 4, pp. 135-137.

Department of Education NSW. (1984), Music K-6 syllabus and support statements, Sydney, Australia: NSW Government.

Dimitriades, G., Cole, E. and Costello, A. (2009), 'The social field(s) of arts education today: Living vulnerability in neo-liberal times', Discourse: Studies in the Cultural Politics of Education, 30: 4, pp. 361369. 
Duncum, P. (1999), 'Primary art pedagogy: Everything a generalist teacher needs to know', Australian Art Education, 21: 3, pp. 15-23.

Dunkin, A. (2004), 'Gliding glissade not grand jete: Elementary classroom teachers teaching dance', Arts Education Policy Review, 105: 3, pp. 23-29.

Gibson, R. and Anderson, M. (2008), 'Touching the void: Arts education research in Australia', Asia Pacific Journal of Education, 28: 1, pp. 103-112.

Hauptfleisch, S. (1997), 'Transforming South African music education: A systems view', University of Pretoria.

Hudson, P. and Hudson, S. (2007), 'Examining preservice teachers' preparedness for teaching art', International Journal of Education \& the Arts, 8: 5, pp. 1-25.

Jeanneret, N. (2006), 'The national review of music in schools and the endless debate about music in primary schools', Australian Journal of Music Education, 1, pp. 93-97.

Jeanneret, N., Brown, R., Bird, J., Sinclair, C., Imms, W., Watkins, M. and Donelan, K. (2006), 'Encounters with engaging pedagogy: Arts education for the pre-service primary generalist', In Backing our creativity: Proceedings from the national education and the arts symposium, (eds.), N. Jeanneret and G. Gardiner. Sydney: Australian Council for the Arts.

Klopper, C. (2004), 'Variables impacting on the delivery of music in the learning area arts and culture in South Africa', University of Pretoria.

Klopper, C. (2007), 'So you gotta teach music! A case for advocacy in regional Australian teacher education', In ASME XVI 40th Anniversary National Conference. Perth, Western Australia.

Montague, J. (2004), 'Policy to practice: Arts Action and support for the non-specialist teacher in the K-6 classroom', In International Society of Music Education Conference, (ed.), D. Forrest. Nedlands WA: International Society for Music Education.

Pascoe, R., Leong, S., MacCallum, J., Mackinlay, J., Marsh, K., Smith, B., Church, T. and Winterton, A. (2005), 'National review of school music education', Australia: Australian Government.

Peers, C. (2008), 'Investigating myths and perceptions of visual arts education: Findings of a pilot study on current practices in visual arts pedagogy in Victorian primary schools', Australian Art Education, 31: 1, pp. 99-123.

Potgieter, H. \& Klopper, C. (2006) 'Lessons in the musical arts classroom from educators and learners'. In The transformation of musical arts education, (ed.), Potgieter, H. Cape Town, North-West University.

Russell-Bowie, D. (1993), 'Where is music education in our primary schools?', Research Studies in Music Education, 1, pp. 52-58.

Russell-Bowie, D. (2002), "Where in the world are we?": How the perceptions of Australian primary teacher education students differ from those from four other countries in relation to their background and confidence in music education', Australian Journal of Music Education, 1, pp. 33-44. 
Russell-Bowie, D. (2006), MMADD about the arts: An introduction to primary arts education, Frenchs Forest: Pearson Education Australia.

Russell-Bowie, D. (2009a), 'Taming the wild beast! Developing preservice primary music education students' confidence and competence', In ASME XVII National Conference. Launceston.

Russell-Bowie, D. (2009b), 'What me? Teach music to my primary class? Challenges to teaching music in primary schools in five countries', Music Education Research, 11: 1, pp. 23-36.

Russell-Bowie, D. and Dowson, M. (2005), 'Effects of background and sex on confidence in teaching the creative arts: Tests of specific hypotheses', In Australian Association for Research in Education Conference. Sydney.

Saebo, A. (2009), 'Challenges and possibilities in Norwegian classroom drama practice', Research in Drama Education: The Journal of Applied Theatre and Performance, 14: 2, pp. 279-294.

Smith, R. and Southcott, J. (2004), 'The effect of policy change on the Australian music curriculum: Inclusivity or de-skilling?', In International Society of Music Education Conference, (ed.), David Forrest. Nedlands, WA: International Society of Music Education.

Snyder, S. (2001), 'Connection, correlation, and integration', Music Educators Journal, 87: 5, pp. 32-40.

Stevens, R. S. (2001), 'Change and stasis in school music education in Victoria: The past informing the future', Australian Journal of Music Education, 1, pp. 19-29.

Schwab, J. J. (1962) 'The concept of discipline'. Educational Record, 197-205.

Schwab, J. J. (1964a) 'The structure of the disciplines: Meaning and significance'. In The structure of knowledge and the curriculmu, (eds.) Ford, G. W. \& Pugno, L. Chicago, Rand McNally.

Schwab, J. J. (1964b) 'The structure of the natural science'. In The structure of knowledge and the curriculum, (eds.) Ford, G. W. \& Pugno, L. Chicago, Rand McNally.

Schwab, J. J. (1973) 'The practical: Translation into curriculum'. School Review, 501-522.

Wiggins, R. and Wiggins, J. (2008), 'Primary music education in the absence of specialists', International Journal of Education \& the Arts, 9, pp. 1-26.

Wright, P. (1999), 'The thought of doing drama scares me to death', Research in Drama Education: The Journal of Applied Theatre and Performance, 4: 2, pp. 227 - 237. 